\title{
Isolation of the Acetyl-CoA Synthase Gene from the Corn Smut Pathogen, Ustilago maydis
}

\author{
By J. A. HARGREAVES ${ }^{1 *}$ AND G. TURNER ${ }^{2} \dagger$ \\ ${ }^{1}$ Department of Agricultural Sciences, University of Bristol, AFRC Institute of Arable Crops \\ Research, Long Ashton Research Station, Bristol BS18 9AF, UK \\ 2 Department of Microbiology, University of Bristol, Bristol BS8 ITD, UK
}

(Received 11 May 1989; accepted 23 June 1989)

The acetyl-CoA synthase ( $a c u A$ ) gene from Ustilago maydis has been isolated using a fragment of the acu 5 gene from Neurospora crassa as a heterologous probe. The $U$. maydis acuA gene transformed $\mathrm{Acu}^{-}$mutants of $U$. maydis to acetate utilization. Transformation was accomplished by integration of the vector sequences into the chromosomal DNA.

\section{INTRODUCTION}

Isolation of the genes expressed during the interaction of a fungal pathogen with its host plant and a knowledge of their regulation will be central to the elucidation of mechanisms unique to the parasitic habit. However, before molecular genetic analysis of such genes can be done, a selection of gene markers needs to be available for gene transfer systems and to aid manipulation of the expression of particular genes of interest.

The basidiomycete maize pathogen, Ustilago maydis, has many advantages for studying both genetic and molecular genetic aspects of pathogenicity. It is amenable to manipulation in the laboratory, growing on defined media as small uninucleate haploid colonies. In addition, the genetics and sexual cycle of this pathogen are relatively well understood, allowing strains to be crossed and recombinants to be recovered (Banuett \& Herskowitz, 1988; Holliday, 1974).

Integrative and multicopy plasmid vectors have been described for the transformation of $U$. maydis (Tsukuda et al., 1988; Wang et al., 1988). In both cases, the Escherichia coli hygromycin B phosphotransferase $\left(\right.$ hyg $\left.B^{\mathrm{R}}\right)$ gene was employed as a selectable marker. However, unlike many other fungi used in molecular genetic studies, homologous wild-type or mutant genes have not yet been developed as selectable markers for gene transfer. The only homologous selectable gene described so far for $U$. maydis is the pyr 3 gene encoding dihydroorotase (Banks \& Taylor, 1988).

Here we report the isolation of the acetyl-CoA synthase (acuA) gene of $U$. maydis and its use as a selectable marker in the transformation of $U$. maydis mutants unable to utilize acetate as the sole carbon source.

\section{METHODS}

Escherichia coli strain and plasmids. E. coli strain DHl (recA palA hsr hsm ${ }^{+}$endo IB relAl) was transformed according to Hanahan (1983). $\mathrm{pC}_{2} \mathrm{~B} 1.0$ carrying a BamHI fragment of the coding region of the acu 5 gene of Neurospora crassa was provided by 1 . Connerton, University of Reading, UK. The plasmid pUC 9 was used as the cloning vector throughout.

$U$. maydis strain and culture conditions. All manipulations were done using an isolate obtained from the CAB International Mycological Institute, Kew, UK, no. 103761. Cultures were maintained on, and sporidia prepared from, a glucose $\left(10 \mathrm{~g} \mathrm{l}^{-1}\right)$ /yeast extract $\left(2 \mathrm{~g} \mathrm{l}^{-1}\right)$ medium (GYE). Minimal medium was as described by Holliday (1974), except that the carbon source $\left(5 \mathrm{~g}^{-1}\right)$ and $50 \mathrm{~mm}$-MOPS (final concentration) were added after autoclaving. Mutants unable to utilize acetate as a carbon source were isolated by selection for resistance to fluoroacetate on minimal medium containing $5 \mathrm{~g}$ fluoroacetate $\mathrm{l}^{-1}$ and $1 \mathrm{~g}_{\text {glucose }} \mathrm{l}^{-1}$. All solutions were adjusted

† Present address: Department of Molecular Biology and Biotechnology, University of Sheffield, Sheffield S10 2TN, UK. 
to $\mathrm{pH} 6.5$ and solid media contained $2 \%(\mathrm{w} / \mathrm{v})$ agar. Cultures were incubated at $25^{\circ} \mathrm{C}$ and liquid cultures were shaken at 150 r.p.m.

Isolation and manipulation of DNA. Total U. maydis DNA was isolated from sporidia grown in GYE medium for $48 \mathrm{~h}$. The sporidia were harvested from $100 \mathrm{ml}$ cultures by centrifugation at $1000 \mathrm{~g}$ for $20 \mathrm{~min}$, then washed with $0.6 \mathrm{M}-\mathrm{KCl}$. Protoplasts were prepared by incubating sporidia with $10 \mathrm{ml}$ Novozyme $234\left(10 \mathrm{mg} \mathrm{ml}^{-1}\right)$ and Cellulase $\mathrm{R} 10\left(10 \mathrm{mg} \mathrm{ml}^{-1}\right)$ in $0.6 \mathrm{M}-\mathrm{KCl}$, for $45-60 \mathrm{~min}$ at $30^{\circ} \mathrm{C}$. The protoplasts were centrifuged at $1000 \mathrm{~g}$ for $20 \mathrm{~min}$ and then washed once with $0.6 \mathrm{M}-\mathrm{KCl}$. DNA was isolated from the protoplasts as described by Rothstein (1985), with the exception that phenol/chloroform extraction was performed twice. This procedure yielded approximately $20 \mu \mathrm{g}$ DNA.

Standard methods were used for other DNA manipulations (Maniatis et al., 1982).

Conditions for Southern transfer and colony hybridization. The transfer of U. maydis genomic DNA from agarose to nylon filters (Hybond-N, Amersham) was in accordance with the manufacturer's instructions. Conditions to obtain specific hybridization between the $N$. crassa fragment and $U$. maydis DNA were optimized as described by Howley et al. (1979). Colony hybridization was as described by Maniatis et al. (1982) and the conditions used were similar to those for Southern hybridization. Analysis of DNA from transformants was done using standard procedures (hybridization in $5 \times \mathrm{SSC}$ at $65^{\circ} \mathrm{C}$ and washes to $0.1 \times \mathrm{SSC}, 0.1 \% \mathrm{SDS} ; 1 \times \mathrm{SSC}$ is $0.15 \mathrm{M}-\mathrm{NaCl}$, 0.015 M-trisodium citrate).

Preparation and transformation of $U$. maydis protoplasts. Sporidia were grown overnight in GYE medium $(100 \mathrm{ml})$ and protoplasts were isolated and transformed as described by Wang et al. (1988), with some minor modifications. Sporidia were incubated with Novozyme $234\left(5 \mathrm{mg} \mathrm{ml}^{-1}\right)$ for $20-30 \mathrm{~min}$ and protoplasts were recovered by centrifugation at $1000 \mathrm{~g}$ for $10 \mathrm{~min}$. Following transformation, the protoplasts were plated out directly on to minimal medium containing sodium acetate and $1 \mathrm{M}$-sorbitol. On this medium it was not possible to clearly differentiate the transformed colonies from background growth, since sorbitol supports limited growth of $U$. maydis. After $5 \mathrm{~d}$ the colonies that grew were replica plated on to minimal medium containing sodium acetate alone and acetate-utilizing colonies appeared 4-5 d later.

\section{RESULTS AND DISCUSSION}

A random primed labelled (Feinberg \& Vogelstein, 1983) $1.0 \mathrm{~kb}$ Bam HI fragment of the $N$. crassa acu 5 gene (Thomas et al., 1988) was used as a hybridization probe against Southern blots of $U$. maydis genomic DNA $(5 \mu \mathrm{g})$, digested with a number of different restriction enzymes. Using a stringency allowing hybridization of sequences with approximately $75 \%$ homology ( $30 \%$ formamide in the hybridization buffer at $35^{\circ} \mathrm{C}$ and washes at $56^{\circ} \mathrm{C}$ in $2 \times \mathrm{SSC}, 0.5 \%$ SDS), the $N$. crassa fragment hybridized to a single HindIII fragment $(7.5 \mathrm{~kb})$. At this stringency, a number of weaker background signals were also observed. U. maydis DNA $(25 \mu \mathrm{g})$ was digested with HindIII and fragments $6.0-8.0 \mathrm{~kb}$ in size were isolated. A partial library (Nicholls, 1986) containing this HindIII fragment was constructed in the plasmid pUC9, and positive clones were identified by hybridization to the $N$. crassa acu 5 gene fragment. One clone (pUCH2) was recovered which contained a $U$. maydis HindIII fragment that gave a strong hybridization signal with the $N$. crassa probe. A partial map of this $U$. maydis HindIII fragment is shown in Fig. 1.

Acetate non-utilizing $\left(\mathrm{Acu}^{-}\right)$mutants were isolated by positive selection for resistance to fluoroacetate as described by Apirion (1965). Resistant colonies ( $f a c$ mutants) appeared after incubation for 6-8 d. Only fac mutants unable to grow on media containing acetate as the sole carbon source were selected for transformation. Four separate $\mathrm{Acu}^{-}$mutants (A7615, A7617, A76120 and A76121) were transformed with $1 \mu \mathrm{g}$ of either pUC9 or pUCH2. Colonies capable of growing on acetate medium were obtained with all the mutants transformed with pUCH2, at frequencies ranging from 5 to 20 colonies per $\mu \mathrm{g}$ DNA. No growth occurred with any of the mutants when pUC9 was used as the transforming DNA. The transformants were mitotically stable when grown in the absence of acetate.

Six transformants from three different mutants (A7615, A7617 and A76121) were selected for Southern blot analysis. In the lanes containing undigested DNA from the transformants (Fig. $2 a$ ), radiolabelled pUC9 hybridized, with one exception (lane 5), to bands corresponding to undigested DNA. This indicates that transformation had occurred by integration of the vector sequences into the chromosomal DNA. No homology was detected between pUC9 sequences and $U$. maydis DNA (Fig. $2 a$, lane C). Digests of $U$. maydis DNA with $S s t \mathrm{I}$ were also probed with either pUC9 or an Sst I/HindIII fragment $(6.8 \mathrm{~kb})$ of the cloned U. maydis HindIII fragment 


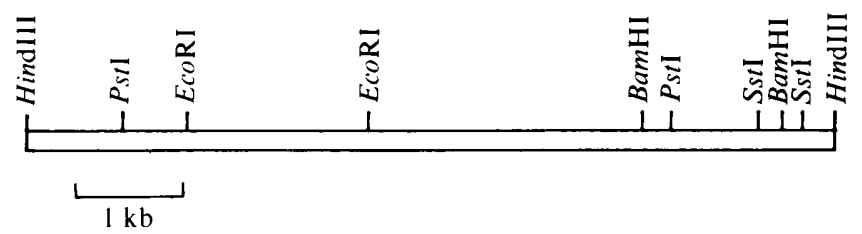

Fig. 1. A restriction endonuclease map of the $U$. maydis HindIII fragment carrying the acuA gene.

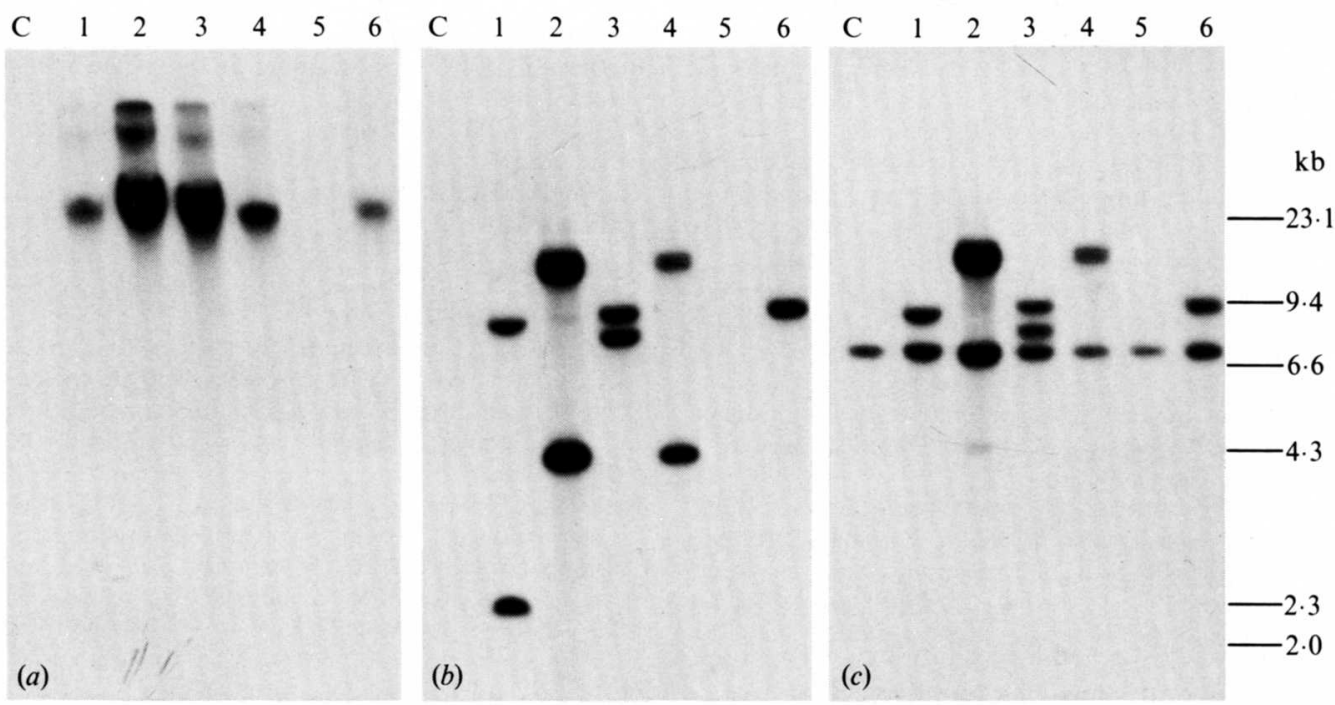

Fig. 2. Southern blot hybridization analysis of $U$. maydis Acu- mutant A7615 (C) and six selected acetate utilizing transformants (1, AT76151; 2, AT76152; 3, AT76171; 4, AT76172; 5, AT761211; 6, AT761212). DNA from the $\mathrm{Acu}^{-}$mutant and the transformants was probed undigested with radiolabelled pUC9 (a) or after Sst I digestion, with either pUC9 (b) or the $6.8 \mathrm{~kb}$ SstI/HindIII fragment from the $U$. maydis HindIII insert $(c)$.

(Fig. $2 b, c$ ). The hybridization signals obtained were consistent with the interpretation that integration of one copy or, in one case, two copies of the vector had occurred by either homologous or heterologous recombination. In the transformant where no hybridization to pUC9 was detected a double cross-over event seems to have led to the mutant gene being replaced by the wild-type gene, with the rest of the vector sequences being lost (Fig. 2b, lane 5). Although it is possible that this transformant arose as a result of a reversion of the $a c u A$ mutation in the recipient strain, this would seem unlikely since no reversions were observed when pUC9 was used alone as the transforming vector. The type of integration events observed here are in general consistent with those reported for other homologous gene transfer systems in fungi (Ballance \& Turner, 1986; Banks \& Taylor, 1988; de Graaff et al., 1988; van Hartingsveldt et al., 1987).

These results indicate that $\mathrm{pUCH} 2$ contains all the necessary control and regulatory sequences to gain expression of the acetyl-CoA synthase gene in $\mathrm{Acu}^{-}$mutants of $U$. maydis. The availability of this and other homologous selectable genes for the transformation will aid the manipulation of gene expression in $U$. maydis using gene replacement or gene disruption techniques.

We are very grateful for the plasmid $\mathrm{pC}_{2} \mathrm{~B} 1.0$ provided by Dr Ian Connerton, University of Reading. 


\section{REFERENCES}

APIRION, D. (1965). The two-way selection of mutants and revertants in respect of acetate utilization and resistance to fluoro-acetate in Aspergillus nidulans. Genetical Research, 6, 317-329.

Ballance, D. J. \& Turner, G. (1986). Gene cloning in Aspergillus nidulans: isolation of the isocitrate lyase gene. Molecular and General Genetics 202, 271-275.

BANKS, G. R. \& TAYLOR, S. Y. (1988). Cloning of the $P Y R 3$ gene of Ustilago maydis and its use in DNA transformations. Molecular and Cellular Biology 8, 5417-5424.

BanUetT, F. \& Herskowitz, I. (1988). Genetic determinants of the life cycle of Ustilago maydis. In Genetics of Phytopathogenic Fungi (Advances in Plant Pathology Series vol. 6), pp 427-455. Edited by G. Sidhu. London: Academic Press.

Feinberg, A. P. \& Vogelstein, B. (1983). A technique for radiolabelling DNA restriction endonuclease fragments to high specific activity. Analytical Biochemistry 132, 6-13.

DE GRAaFF, L., VAN DEN BRoEK, H. \& VisSER, J. (1988). Isolation and transformation of the pyruvate kinase gene of Aspergillus nidulans. Current Genetics 13, 315-321.

HaNaHAN, D. (1983). Studies on transformation of Escherichia coli with plasmids. Journal of Molecular Biology 166, 557-580.

van Hartingsveldt, W., Mattern, I. E., van ZeiJl, C. M. J., Pouwels, P. H. \& VAN DEN Hondel, C. A. M. J. J. (1987). Development of a homologous transformation system for Aspergillus niger based on the pyrG gene. Molecular and General Genetics 206, 71-75.
Holliday, R. (1974). Ustilago maydis. In Handbook of Genetics, vol. 1, pp. 575-595. Edited by R. C. King. New York: Plenum Press.

Howley, P. M., IsRael, M. A., Law, Ming-Fan \& MARTIN, M. A. (1979). A rapid method for detecting and mapping homology between heterologous DNAs. Journal of Biological Chemistry 254, 48764883.

Maniatis, T., Fritsch, E. F. \& Sambrook, J. (1982). Molecular Cloning, a Laboratory Manual. Cold Spring Harbor, NY: Cold Spring Harbor Laboratory.

Nicholls, R. D. (1986). Direct cloning in plasmid libraries after fragment enrichment. Focus 8, 1-3.

RothsteIN, R. (1985). Cloning in yeast. In DNA Cloning: a Practical Approach, vol II, pp. 45-66. Edited by D. M. Glover. Oxford \& Washington: IRL Press.

Thomas, G. H., Connerton, I. F. \& Fincham, J. R. S. (1978). Molecular cloning, identification and transcriptional analysis of genes involved in acetate utilization in Neurospora crassa. Molecular Microbiology 2, 599-606.

Tsukuda, T., Carleton, S., Fotheringham, S. \& Holloman, W. K. (1988). Isolation and characterization of an autonomously replicating sequence from Ustilago maydis. Molecular and Cellular Biology 8, 3703-3709.

Wang, J., Holden, D. W. \& LeONG, S. A. (1988). Gene transfer system for the phytopathogenic fungus Ustilago maydis. Proceedings of the National Academy of Sciences of the United States of America 85, 865-869 